\title{
Hydrogen peroxide generated by xanthine/ xanthine oxidase system represses the proliferation of colorectal cancer cell line Caco-2
}

\author{
Satoru Sakuma, Muneyuki Abe, Tetsuya Kohda and Yohko Fujimoto* \\ Laboratory of Physiological Chemistry, Osaka University of Pharmaceutical Sciences, 4-20-1 Nasahara, Takatsuki, Osaka 569-1094, Japan
}

(Received 26 February, 2014; Accepted 7 May, 2014; Published online 28 November, 2014)

\begin{abstract}
The twin character of reactive oxygen species is substantiated by a growing body of evidence that reactive oxygen species within cells act as inducers and accelerators of the oncogenic phenotype of cancer cells, while reactive oxygen species can also induce cancer cell death and can therefore function as anti-tumorigenic species. The aim of this study was to assess a possible influence of xanthine/xanthine oxidase on the proliferation of colorectal cancer cell line Caco-2. xanthine/xanthine oxidase $(2.5 \mu \mathrm{M} / 0.25 \mathrm{mU} /$ $\mathrm{ml}-25 \mu \mathrm{M} / 2.5 \mathrm{mU} / \mathrm{ml}$ ) dose-dependently inhibited the proliferation of Caco-2 cells. Experiments utilizing reactive oxygen species scavengers (superoxide dismutase, catalase and mannitol) and exogenous hydrogen peroxide revealed a major role of hydrogen peroxide in the xanthine/xanthine oxidase effect. Investigations utilizing annexin V-fluorescein/PI assay using flow cytometry, and the lactate dehydrogenase extracellular release assay indicated that hydrogen peroxide induced necrosis, but not apoptosis, in Caco-2 cells. These results suggest that hydrogen peroxide generated by xanthine/xanthine oxidase has the potential to suppress colorectal cancer cell proliferation.
\end{abstract}

Key Words: $\quad$ xanthine/xanthine oxidase, hydrogen peroxide, colon cancer, proliferation, reactive oxygen species

$\mathrm{C}$ olorectal cancer is one of the leading causes of death worldwide, being responsible for approximately $10 \%$ of total cancer-related mortality. ${ }^{(1)}$ About $3-5 \%$ of colorectal cancers may be due to inherited genetic defects and up to $25 \%$ of patients may have some degree of familiarity for this disease, but the majority of colorectal cancers occur in a sporadic manner in the absence of a documented family history. (2)

Reactive oxygen species (ROS) are well recognized for playing a dual role as both deleterious and beneficial species. Oxidative damage primarily mediated by ROS accumulates during the life cycle, and ROS-related damage to DNA, proteins and lipids has been proposed to play a key role in the development of various cancers including colorectal cancer. ${ }^{(3)}$ In contrast, it is known that ROS can induce cellular senescence and cell death, and can therefore function as anti-tumorigenic species. Indeed, ROS are important mediators for anti-neoplastic therapy including chemotherapy, ionizing radiation, ultraviolet radiation, and possibly photodynamic therapy. ${ }^{(4-6)}$

The enzyme xanthine oxidase (XO), which catalyzes conversion of hypoxanthine and xanthine (X) into uric acid, uses oxygen as redox partner, thus producing ROS, mainly superoxide anion radicals $\left(\mathrm{O}_{2}{ }^{--}\right)$and hydrogen peroxide $\left(\mathrm{H}_{2} \mathrm{O}_{2}\right)$. XO is known to circulate in many species including humans. ${ }^{(7)}$ There is evidence of a significant rise in plasma XO levels during pathological con- ditions, for example in human liver disease ${ }^{(7)}$ and pancreatitis. ${ }^{(8)}$ Besides, Partridge et al. ${ }^{(9)}$ have demonstrated a process of cell death-independent, constitutive release of XO from cultured bovine pulmonary microvascular endothelial cells. An attractive role for circulating XO lies in a putative function as an antimicrobial agent, and both circumstantial and direct evidence exists for this function. Circulating XO may bind to glycosaminoglycans, ${ }^{(10)}$ which are similar to structural components found on the surface of some bacteria. Therefore, by utilizing a circulating substrate the enzyme can generate microbicidal ROS in close proximity to microbes. Indeed, the antimicrobial function of XO has been widely demonstrated in milk, ${ }^{(11)}$ where it is believed that XO-generating ROS afford protection to the suckling neonate from diseases, such as gastroenteritis, in the early postpartum period. This mechanism has also been shown to be effective in Cape Buffalo where an anti-microbial role for circulating XO in the control of trypanosome infection has been established. ${ }^{(12)}$

In the present study, to explore further physiological or pathological role of $\mathrm{X} / \mathrm{XO}$-mediated ROS, we investigated the effect of $\mathrm{X} / \mathrm{XO}$ on the proliferation of a colorectal cancer cell line, Caco-2 cells.

\section{Materials and Methods}

Materials. Xanthine, $\mathrm{H}_{2} \mathrm{O}_{2}$, superoxide dismutase (SOD), catalase (CAT), 3-(4,5-dimethylthiazol-2-yl)-2,5-diphenyl tetrazolium bromide (MTT), propidium iodide (PI), mannitol and camptothecin were purchased from Sigma-Aldrich Corporation (St. Louis, MO). XO was obtained from Roche Diagnostics Corporation (Indianapolis, IN). Annexin V-fluorescein staining kit was obtained from Wako Pure Chem. Ind., Ltd. (Osaka, Japan). Camptothecin was dissolved in dimethyl sulfoxide (DMSO) and added to medium; the DMSO concentration $(0.25 \%)$ used in the present study had no significant effect on Caco-2 proliferation.

Cell culture. Caco-2 human colon cancer cell lines were purchased from the European Collection of Cell Cultures (Salisbury, Wilts, UK) and cultured in Minimum Essential Medium (MEM; Life Technologies Corporation, Carlsbad, CA) supplemented with 10\% FBS (Nichirei Biosciences Inc., Tokyo, Japan) and $1 \%$ non-essential amino acids (Life Technologies Corporation, Carlsbad, CA). The cells were maintained in a humidified atmosphere of $5 \% \mathrm{CO}_{2}$ at $37^{\circ} \mathrm{C}$.

Cell viability assay. Cell viability was measured by MTT assay, as we described previously. ${ }^{(13,14)}$ Briefly, the cells were

*To whom correspondence should be addressed.

E-mail: fujimoto@gly.oups.ac.jp 
incubated with the test reagents at a density of $2.5 \times 10^{4}$ cells $/ 2 \mathrm{ml} /$ $9.5 \mathrm{~cm}^{2}$ well for $24 \mathrm{~h}$. After incubation, the medium was removed and the cells were incubated with $1.1 \mathrm{ml}$ of MTT solution $(0.1 \mathrm{ml}$ of $5 \mathrm{mg} / \mathrm{ml}$ MTT in $1 \mathrm{ml}$ of medium) for $4 \mathrm{~h}$. The product was eluted from cells by the addition of $20 \% \mathrm{SDS} / 0.01 \mathrm{M} \mathrm{HCl}$, and absorbance at $595 \mathrm{~nm}$ was determined using an SH-1000Lab microplate reader (Corona Electric Co., Ltd., Ibaraki, Japan). Cell viability was calculated according to the following equation: cell viability $(\%)=($ absorbance of experiment group/absorbance of control group) $\times 100$.

Determination of cell apoptosis or necrosis. Apoptosis or necrosis was detected by flow cytometry using an annexin Vfluorescein staining kit. Briefly, the cells were incubated with $\mathrm{H}_{2} \mathrm{O}_{2}$ or camptothecin at a density of $1.0 \times 10^{6}$ cells $/ 10 \mathrm{ml} / 55 \mathrm{~cm}^{2}$ dish for $24 \mathrm{~h}$, and then collected by centrifugation. The cell pellets were incubated with staining solution containing annexin Vfluorescein and PI at room temperature for $15 \mathrm{~min}$. After adequate dilution according to the cell density, the samples were filtrated through a nylon mesh $(35 \mu \mathrm{m})$, and subjected to a FACScan ${ }^{\mathrm{TM}}$ flow cytometer (Becton, Dickinson and Company, Franklin Lakes, NJ).

Cytotoxicity assay. Cytotoxicity was assessed by a Cyto Tox96 ${ }^{\circledR}$ Non-Radioactive Cytotoxicity Assay (Promega Corporation, Madison, WI) based on exocytic release of lactate dehydrogenase (LDH). The cells were incubated with $\mathrm{H}_{2} \mathrm{O}_{2}$ at a density of $2.5 \times 10^{4}$ cells $/ 2 \mathrm{ml} / 9.5 \mathrm{~cm}^{2}$ well for $24 \mathrm{~h}$. After incubation, the medium was collected, and cells were harvested and destroyed by freeze-thawing $\left(-80^{\circ} \mathrm{C}, 30 \mathrm{~min} ; 37^{\circ} \mathrm{C}, 30 \mathrm{~min}\right)$. The collected medium and cell destruction sample were centrifuged at $780 \times g$ for $5 \mathrm{~min}$, and the supernatants were then used with a Cyto Tox $96^{\circledR}$ Non-Radioactive Cytotoxicity Assay kit. The product absorbance was measured with an SH-1000Lab microplate reader at a wavelength of $490 \mathrm{~nm}$. Cytotoxicity was expressed as LDH release according to the following equation: LDH release $(\%)=$ (extracellular LDH activity/total LDH activity) $\times 100$.

Statistics. Results are the means \pm SEM. The significance of differences between two groups was assessed using the Student's $t$ test, and differences between multiple groups were assessed by one-way analysis of variance (ANOVA), followed by Scheffe's multiple range test. $P$ values less than 0.05 were considered significant.

\section{Results}

$\mathrm{X} / \mathrm{XO}$ system suppressed the proliferation of Caco- 2 cells. Fig. 1 illustrates a dose-dependent alteration in Caco-2 cell growth by the $\mathrm{X} / \mathrm{XO}$ system. When Caco-2 cells were incubated with $\mathrm{X} / \mathrm{XO}$ at concentrations ranging from $2.5 \mu \mathrm{M} / 0.25 \mathrm{mU} / \mathrm{ml}$ to $25 \mu \mathrm{M} / 2.5 \mathrm{mU} / \mathrm{ml}$, a dose-dependent suppression in cell growth was obtained, and the inhibition reached $52 \%$ of the control value at $12.5 \mu \mathrm{M} \mathrm{X} / 1.25 \mathrm{mU} / \mathrm{ml} \mathrm{XO}$. Addition of X $(12.5 \mu \mathrm{M})$ and denatured XO $(1.25 \mathrm{mU} / \mathrm{ml} \mathrm{XO}$ was boiled for $5 \mathrm{~min}$ before use) to Caco-2 cells did not show any significant effect on the cell growth, implying an inhibitory role of a certain product formed by the enzymatic reaction.

$\mathrm{H}_{2} \mathrm{O}_{2}$ formed from $X / X O$ system induced a suppression of Caco-2 proliferation. It has been known that $\mathrm{XO}$ generates $\mathrm{O}_{2}{ }^{\cdot-}$ and $\mathrm{H}_{2} \mathrm{O}_{2}$ in the presence of oxygen as an electron acceptor. There is also a possibility that trace metal ions $\left(\mathrm{Fe}^{2+}, \mathrm{Cu}^{2+}\right.$, etc. $)$ in vital cells catalyze the production of hydroxyl radicals $\left({ }^{\circ} \mathrm{OH}\right)$ from $\mathrm{H}_{2} \mathrm{O}_{2}$. SOD catalyzes the dismutation of $\mathrm{O}_{2}{ }^{--}$to $\mathrm{O}_{2}$ and $\mathrm{H}_{2} \mathrm{O}_{2}$. CAT decomposes $\mathrm{H}_{2} \mathrm{O}_{2}$ to form water. To clarify a possible involvement of $\mathrm{O}_{2}^{--}, \mathrm{H}_{2} \mathrm{O}_{2}$ or ${ }^{\circ} \mathrm{OH}$ in the inhibition of cell proliferation elicited by the X/XO system, the effects of SOD, CAT, mannitol (an effective $\mathrm{OH}$ scavenger ${ }^{(15,16)}$ ) on the $\mathrm{X} / \mathrm{XO}$ effect and of exogenous $\mathrm{H}_{2} \mathrm{O}_{2}$ were examined (Fig. 2 and 3, and Table 1). As shown in Fig. 2, co-addition of SOD at concentrations of 0.02 , 0.1 and $0.5 \mathrm{U} / \mathrm{ml}$ had no significant effect on the $\mathrm{X} / \mathrm{XO}(12.5 \mu \mathrm{M} /$

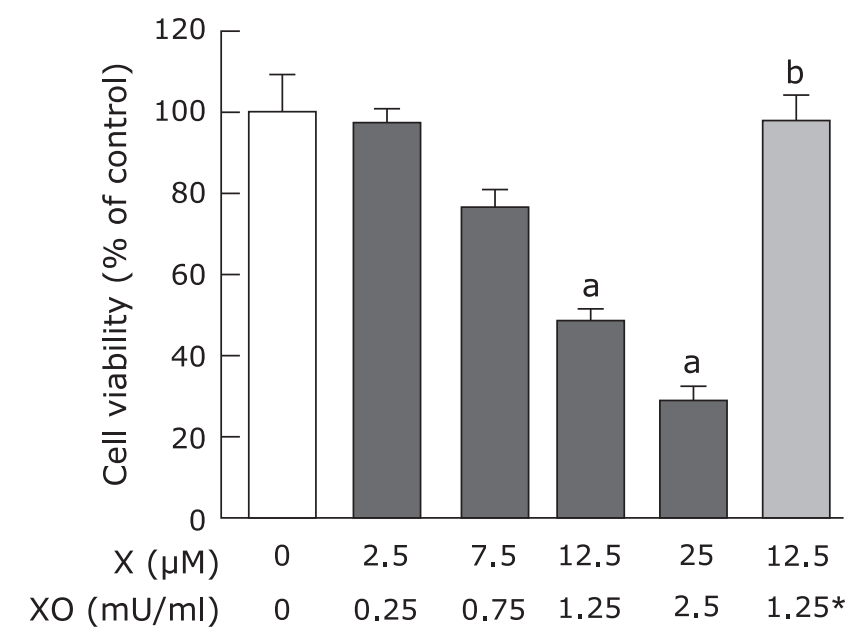

Fig. 1. Effect of $X / X O$ on the proliferation of Caco-2 cells. Caco-2 cells were treated with xanthine/xanthine oxidase $(X / X O)$ for $24 \mathrm{~h}$. Proliferation was assayed by an MTT. $* 1.25 \mathrm{mU} / \mathrm{ml}$ XO was boiled at $100^{\circ} \mathrm{C}$ for $10 \mathrm{~min}$. Data are expressed as the mean $\pm \operatorname{SEM}(n=3) .{ }^{a} p<0.01$; significantly different from the corresponding value in the absence of X/XO. ${ }^{b} p<0.01$; significantly different from the corresponding value in the presence of $12.5 \mu \mathrm{M} \mathrm{X} / 1.25 \mathrm{mU} / \mathrm{ml}$ XO.

$1.25 \mathrm{mU} / \mathrm{ml}$ )-induced inhibition of Caco-2 proliferation. In contrast, co-addition of CAT at the same concentration range dose-dependently attenuated the suppression of Caco- 2 proliferation by $\mathrm{X} / \mathrm{XO}$, and almost nullified the $\mathrm{X} / \mathrm{XO}$ effect at $0.5 \mathrm{U} / \mathrm{ml}$. This CAT action completely disappeared when the enzyme was denatured by boiling. As shown in Fig. 3, exogenously added $\mathrm{H}_{2} \mathrm{O}_{2}$ at concentrations of up to $50 \mu \mathrm{M}$ decreased Caco-2 proliferation in a dose-dependent manner $\left(20 \mu \mathrm{M} \mathrm{H}_{2} \mathrm{O}_{2}, 38 \%\right.$ inhibition). Also, co-addition of mannitol (10 and $100 \mathrm{mM})$ did not attenuate the suppression of Caco-2 proliferation by $\mathrm{X} / \mathrm{XO}$ $(12.5 \mu \mathrm{M} / 1.25 \mathrm{mU} / \mathrm{ml})$ or $\mathrm{H}_{2} \mathrm{O}_{2}(20 \mu \mathrm{M})$ (Table 1). Results shown in Fig. 2 and 3, and Table 1 showed that the $\mathrm{X}-\mathrm{XO}$ action was not due to $\mathrm{O}_{2}{ }^{--}$and ${ }^{\circ} \mathrm{OH}$, and was mainly due to $\mathrm{H}_{2} \mathrm{O}_{2}$.

$\mathrm{H}_{2} \mathrm{O}_{2}$ induced necrosis on Caco-2 cells. Fig. 4 illustrates the percentages of necrotic or apoptotic cells, measured by the annexin V-fluorescein/PI assay using flow cytometry, when Caco-2 cells were exposed to $\mathrm{H}_{2} \mathrm{O}_{2}(20 \mu \mathrm{M})$ at $24 \mathrm{~h}$. Positive staining with annexin V-fluorescein correlates with a loss of membrane polarity, and a complete loss of membrane integrity will lead to apoptosis or necrosis. In contrast, PI can only enter cells after the complete loss of membrane integrity. The fraction of the cell population in different quadrants was analyzed using quadrant statistics. ${ }^{(17)}$ Cells in the upper left quadrant [B: annexin $\mathrm{V}(-) / \mathrm{PI}(+)]$ represented necrotic cells. Cells in the lower right quadrant $[\mathrm{C}$ : annexin $\mathrm{V}(+) / \mathrm{PI}(-)]$ represented early apoptotic cells, and cells in the upper right quadrant [D: annexin $\mathrm{V}(+) / \mathrm{PI}(+)]$ represented late apoptotic cells (a representative analytic datum of the control is shown in the left-hand side of Fig. 4). The experiment using camptothecin, which is a known inducer of apoptosis, ${ }^{(18)}$ verified the validity of the cell analysis; $10 \mu \mathrm{M}$ camptothecin significantly increased the early apoptotic cell population (C). The treatment of Caco-2 cells with $20 \mu \mathrm{M} \mathrm{H}_{2} \mathrm{O}_{2}$ induced a significant increase in the necrotic cell population (B).

Furthermore, an extracellular release of $\mathrm{LDH}$, which is known to be a necrosis indicator, ${ }^{(19)}$ was measured during incubation with $\mathrm{H}_{2} \mathrm{O}_{2} ; 20 \mu \mathrm{M} \mathrm{H}_{2} \mathrm{O}_{2}$ showed about two-fold increase in the $\mathrm{LDH}$ extracellular release [control, $8.6 \pm 1.1 ; \mathrm{H}_{2} \mathrm{O}_{2}, 17.8 \pm 0.4$ $(n=3 ; p<0.01)(\%$ of total LDH activity $)]$.

These findings revealed that $\mathrm{H}_{2} \mathrm{O}_{2}$ induced necrosis, but not apoptosis, in Caco- 2 cells. 


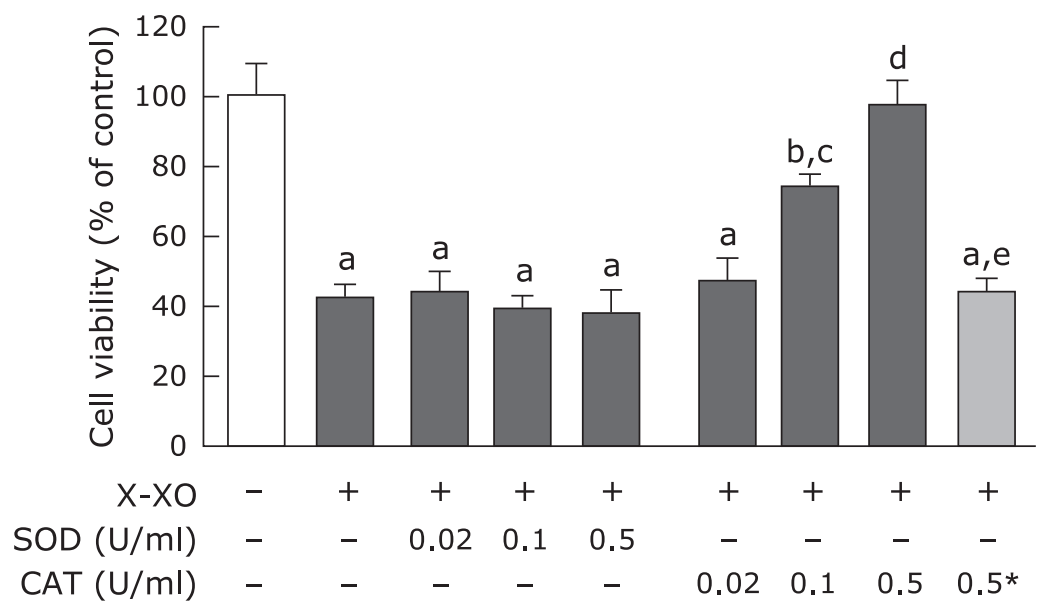

Fig. 2. Effect of $X / X O$ in the presence of SOD or CAT on the proliferation of Caco-2 cells. Caco-2 cells were treated with $12.5 \mu M$ xanthine (X)/ $1.25 \mathrm{mU} / \mathrm{ml}$ xanthine oxidase (XO) in the presence of superoxide dismutase (SOD) or catalase (CAT) for $24 \mathrm{~h}$. Proliferation was assayed by an MTT. ${ }^{*} 0.5 \mathrm{U} / \mathrm{ml} \mathrm{CAT}$ was boiled at $100^{\circ} \mathrm{C}$ for $10 \mathrm{~min}$. Data are expressed as the mean $\pm \mathrm{SEM}(n=3-4)$. ${ }^{\mathrm{a}} p<0.01,{ }^{\mathrm{b}} p<0.05$; significantly different from the corresponding value in the absence of $X / X O$, SOD and CAT. ${ }^{c} p<0.05,{ }^{d} p<0.01$; significantly different from the corresponding value in the presence of $X / X O$. ${ }^{~} p<0.01$; significantly different from the corresponding value in the presence of $X / X O$ and $0.5 \mathrm{U} / \mathrm{ml}$ CAT.

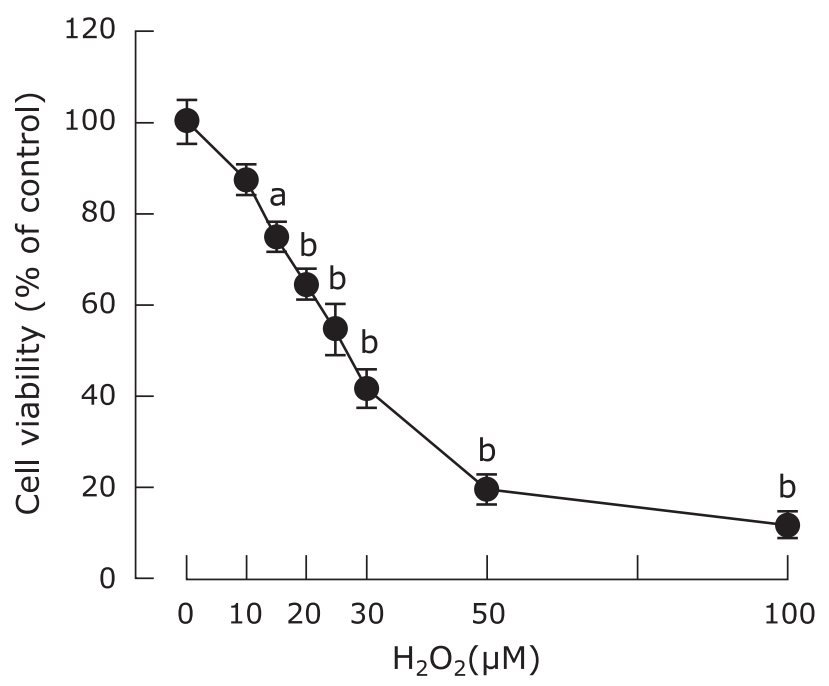

Fig. 3. Effect of $\mathrm{H}_{2} \mathrm{O}_{2}$ on the proliferation of Caco-2 cells. Caco-2 cells were treated with hydrogen peroxide $\left(\mathrm{H}_{2} \mathrm{O}_{2}\right)$ for $24 \mathrm{~h}$. Proliferation was assayed by an MTT. Data are expressed as the mean \pm SEM $(n=3-4)$. ${ }^{a} p<0.05,{ }^{b} p<0.01$; significantly different from the corresponding value in the absence of $\mathrm{H}_{2} \mathrm{O}_{2}$.

Table 1. Effects of $X / X O$ and $\mathrm{H}_{2} \mathrm{O}_{2}$ in the presence of mannitol on the proliferation of Caco-2 cells

\begin{tabular}{|c|c|c|c|}
\hline Treatment & & & Cell viability \\
\hline & & & \\
\hline \multirow{4}{*}{$\begin{array}{l}\text { Control } \\
X / X O\end{array}$} & & & $100.0 \pm 5.2$ \\
\hline & & & $33.8 \pm 0.5^{\mathrm{a}}$ \\
\hline & + mannitol & $10 \mathrm{mM}$ & $31.0 \pm 1.4$ \\
\hline & & $100 \mathrm{mM}$ & $30.0 \pm 1.6$ \\
\hline \multirow[t]{3}{*}{$\mathrm{H}_{2} \mathrm{O}_{2}$} & & & $46.0 \pm 0.8^{a}$ \\
\hline & + mannitol & $10 \mathrm{mM}$ & $37.9 \pm 0.9$ \\
\hline & & $100 \mathrm{mM}$ & $33.0 \pm 1.7$ \\
\hline
\end{tabular}

Caco-2 cells were incubated with or without $12.5 \mu \mathrm{M}$ xanthine $(\mathrm{X}) /$ $1.25 \mathrm{mU} / \mathrm{mll}$ xanthine oxidase (XO) or $20 \mu \mathrm{M} \mathrm{H}_{2} \mathrm{O}_{2}$ in the presence or absence of indicated concentrations of mannitol for $24 \mathrm{~h}$. Proliferation was assayed by an MTT. Data are expressed as the means \pm SEM $(n=4-5)$. ${ }^{a} p<0.01$; significantly different from control.

\section{Discussion}

In the present study, using Caco-2 cell lines, we investigated a possible role of $\mathrm{X} / \mathrm{XO}$ in colorectal cancer cell proliferation. We found that $\mathrm{X} / \mathrm{XO}$ at a concentration of $12.5 \mu \mathrm{M} / 1.25 \mathrm{mU} / \mathrm{ml}$ or higher potently decreased the cell viability of Caco-2 cells. Experiments utilizing ROS scavengers (SOD, CAT and mannitol) and exogenous $\mathrm{H}_{2} \mathrm{O}_{2}$ revealed a major role of $\mathrm{H}_{2} \mathrm{O}_{2}$ in the inhibition of Caco-2 proliferation elicited by $\mathrm{X} / \mathrm{XO}$. Investigations by annexin V-fluorescein/PI assay using flow cytometry and an LDH extracellular release assay indicated that $\mathrm{H}_{2} \mathrm{O}_{2}$ induced necrosis, but not apoptosis, in Caco-2 cells.

$\mathrm{Wu}$ et al. ${ }^{(20)}$ noted that cyclooxygenase-2 (COX-2) expression is dysregulated in many types of cancer including colorectal cancer, and COX-2-derived eicosanoids elicit multiple oncogenic signals to promote carcinogenesis. We therefore examined the effect of $\mathrm{H}_{2} \mathrm{O}_{2}$ on the mRNA and protein expression of COX-2 in Caco-2 cells using real-time RT-PCR and western blotting at 6-h, 12-h or 24-h incubation. $20 \mu \mathrm{M} \mathrm{H}_{2} \mathrm{O}_{2}$ did not have any significant effect on either COX-2 mRNA nor protein expression levels when compared to controls (data not shown). Thus, it seems likely that $\mathrm{H}_{2} \mathrm{O}_{2}$ inhibits Caco-2 proliferation independently of COX-2. Further studies are needed to clarify the mechanism of inhibition of Caco-2 proliferation induced by $\mathrm{H}_{2} \mathrm{O}_{2}$ or X/XO.

Cells are able to detoxify excessive oxidative stressors before they react with vulnerable cellular targets. Enzymes such as SOD and CAT play key roles in the cellular defense against free radical damage. ${ }^{(21)}$ In fact, when $12.5 \mu \mathrm{M} / 1.25 \mathrm{mU} / \mathrm{ml} \mathrm{X} / \mathrm{XO}$ or $20 \mu \mathrm{M} \mathrm{H}_{2} \mathrm{O}_{2}$ was incubated with primary rat hepatocyte cultures prepared according to our previous report ${ }^{(22)}$ for $24 \mathrm{~h}$, there was no significant alteration in the cell viability [MTT assay $(\%$ of control): control, $100.0 \pm 8.2 ; \mathrm{X} / \mathrm{XO}, 96.4 \pm 9.3 ; \mathrm{H}_{2} \mathrm{O}_{2}, 101.2 \pm$ $8.9(n=3)$ ]. This may mean that normal cells have a cellular defense system against the oxidative stress induced by $\mathrm{X} / \mathrm{XO}$ and $\mathrm{H}_{2} \mathrm{O}_{2}$. However, a wide body of data indicates that animal tumor cells including colon cancer cells lack the complex enzyme systems that normally exert protection by scavenging toxic free radicals such as $\mathrm{O}_{2}^{--}, \mathrm{H}_{2} \mathrm{O}_{2}$ and lipid hydroperoxides. ${ }^{(23)}$ Dreher and Junod ${ }^{(24)}$ reported that low levels of oxidative stress stimulate cell proliferation, whereas high levels induce cytotoxicity and cell death in later stages of carcinogenesis. Thus, there is a possibility that Caco-2 cells are sensitive to $\mathrm{H}_{2} \mathrm{O}_{2}$ by their inherent characteristics as malignant tumors, and are thus led to necrosis. 


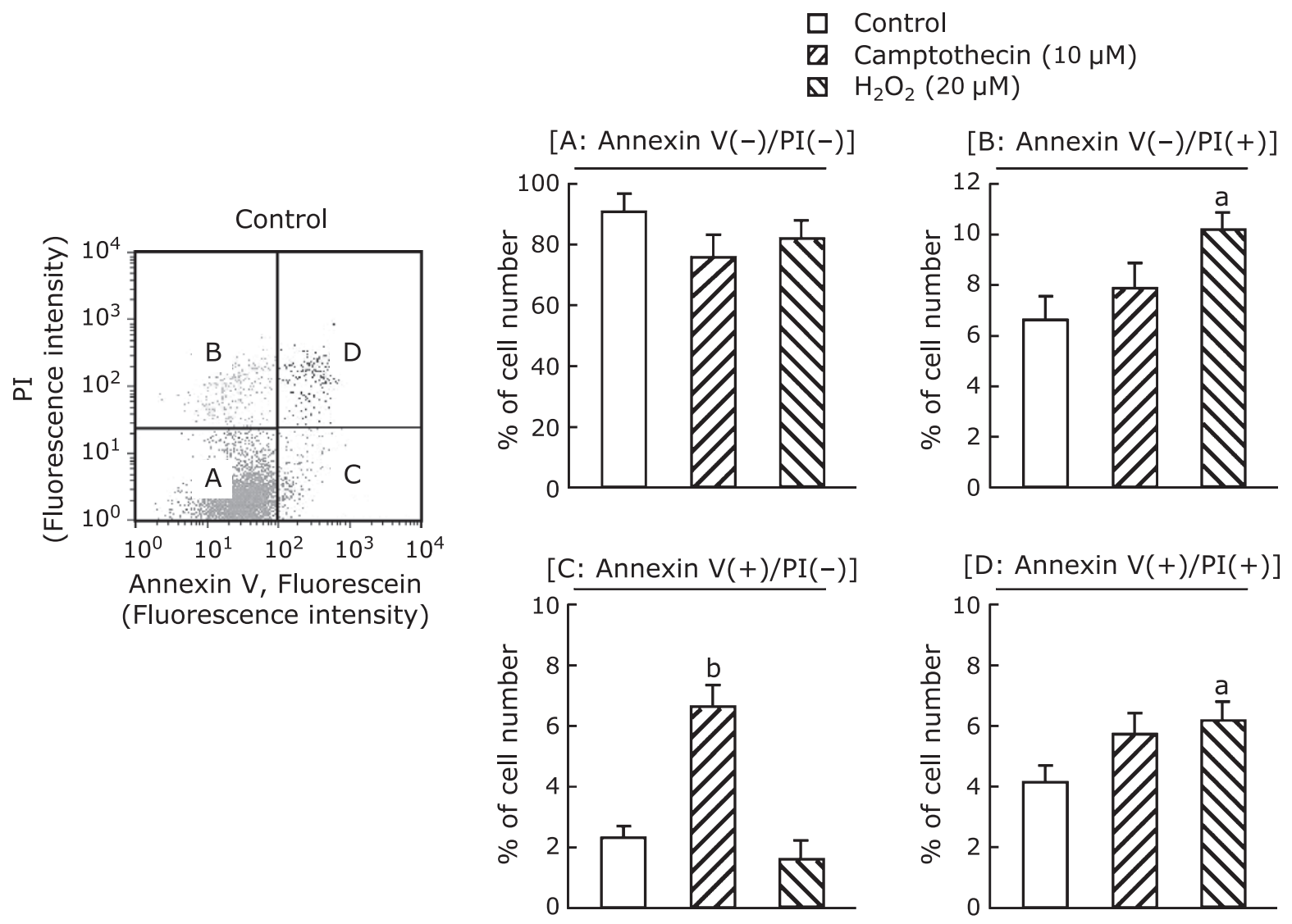

Fig. 4. Effect of $\mathrm{H}_{2} \mathrm{O}_{2}$ on apoptosis or necrosis in Caco-2 cells. Caco-2 cells were treated with $20 \mu \mathrm{M}$ hydrogen peroxide $\left(\mathrm{H}_{2} \mathrm{O}_{2}\right)$ or $10 \mu \mathrm{M}$ camptothecin for $24 \mathrm{~h}$. Apoptosis or necrosis was detected by flow cytometry using an annexin $\mathrm{V}$-fluorescein staining kit. A representative analytic datum of the control is shown on the left-hand side. Data are expressed as the mean \pm SEM $(n=4)$. ${ }^{a} p<0.05,{ }^{b} p<0.01$; significantly different from control.

In a large population-based cohort of breast cancer, Linder et $a .^{(25)}$ showed that XO was down-regulated in more than half of the breast tumors studied, and that absence of XO was an independent predictor of unfavorable outcome. They also demonstrated that the down-regulation of $\mathrm{XO}$ is common in patients with gastric cancer and associated with unfavorable disease-specific survival. ${ }^{(26)}$ Furthermore, their group assessed $\mathrm{XO}$ expression in the foci of 478 patients with colorectal cancer. They found that $\mathrm{XO}$ was decreased in $62 \%$ and undetectable in $22 \%$ of the tumors as compared to normal tissues, and thus concluded that XO expression was associated with the histological grade of differentiation and extent of disease in colorectal cancer. ${ }^{(27)}$ The circulating XO has been shown to bind to, and to be endocytosed by the vascular endothelium. ${ }^{(28)}$ Normal serum XO concentrations determined by ELISA have been estimated to be up to $1 \mathrm{mU} / \mathrm{ml}^{\left({ }^{(7)}\right.}$ In systemic inflammation, XO has also been reported to be present in human plasma at concentrations of up to $1.5 \mathrm{mU} / \mathrm{ml}^{(29)}$ In the present study, we observed that $\mathrm{H}_{2} \mathrm{O}_{2}$ generated by $\mathrm{XO}$ at a concentration of $1.25 \mathrm{mU} / \mathrm{ml}$ or higher reduces the proliferation of colorectal cancer cells Caco- 2 partially by an induction of necrosis. These findings might indicate an important role of circulating $\mathrm{XO}$ and the formed $\mathrm{H}_{2} \mathrm{O}_{2}$ as an endogenous suppressor of colon cancer proliferation, and consequently also progression and metastasis.

\section{Abbreviations}

$\begin{array}{ll}\text { CAT } & \text { catalase } \\ \text { COX } & \begin{array}{l}\text { cyclooxygenase } \\ \text { dimethyl sulfoxide }\end{array} \\ \text { DMSO } & \text { lactate dehydrogenase } \\ \text { LDH } & \text { Minimum Essential Medium } \\ \text { MEM } & \text { 3-(4,5-dimethylthiazol-2-yl)-2,5-diphenyl tetrazolium } \\ \text { MTT } & \text { bromide } \\ & \text { propidium iodide } \\ \text { PI } & \text { reactive oxygen species } \\ \text { ROS } & \text { superoxide dismutase } \\ \text { SOD } & \text { xanthine oxidase } \\ \text { XO } & \end{array}$

\section{Conflict of Interest}

No potential conflicts of interest were disclosed.

\section{References}

1 Stelzner F. Spontaneous change of malignancy of solid malignant tumors: statistical investigations of colorectal and pancreatic carcinoma. Chirurg 2012; 83: 726-731 (in German).

2 Link A, Balaguer F, Shen Y, et al. Curcumin modulates DNA methylation in

colorectal cancer cells. PLos One 2013; 8: e57709.

3 Valko M, Rhodes CJ, Moncol J, Izakovic M, Mazur M. Free radicals, metals and antioxidants in oxidative stress-induced cancer. Chem Biol Interact 2006; 160: 1-40. 
4 Sibata CH, Colussi VC, Oleinick NL, Kinsella TJ. Photodynamic therapy in oncology. Expert Opin Pharmacother 2001; 2: 917-927.

5 Renschler MF. The emerging role of reactive oxygen species in cancer therapy. Eur J Cancer 2004; 40: 1934-1940.

6 Wang J, Yi J. Cancer cell killing via ROS: to increase or decrease, that is the question. Cancer Biol Ther 2008; 7: 1875-1884.

7 Battelli MG, Musiani S, Valgimigli M, et al. Serum xanthine oxidase in human liver disease. Am J Gastroenterol 2001; 96: 1194-1199.

8 Folch E, Salas A, Prats N, et al. $\mathrm{H}_{2} \mathrm{O}_{2}$ and PARS mediate lung P-selectin upregulation in acute pancreatitis. Free Radic Biol Med 2000; 28: 1286-1294.

9 Partridge CA, Blumenstock FA, Malik AB. Pulmonary microvascular endothelial cells constitutively release xanthine oxidase. Arch Biochem Biophys 1992; 294: 184-187.

10 Adachi T, Fukushima T, Usami Y, Hirano K. Binding of human xanthine oxidase to sulphated glycosaminoglycans on the endothelial-cell surface. Biochem J 1993; 289: 523-527.

11 Stevens CR, Millar TM, Clinch JG, Kanczler JM, Bodamyali T, Blake DR. Antibacterial properties of xanthine oxidase in human milk. Lancet 2000; 356: 829-830.

12 Wang J, Van Praagh A, Hamilton E, et al. Serum xanthine oxidase: origin, regulation, and contribution to control of trypanosome parasitemia. Antioxid Redox Signal 2002; 4: 161-178.

13 Sakuma S, Sumi H, Kohda T, Arakawa Y, Fujimoto Y. Effect of lipid peroxidation-derived products on the growth of human colorectal cancer cell line HT-29. J Clin Biochem Nutr 2009; 45: 171-177.

14 Kohda T, Sakuma S, Abe M, Fujimoto Y. Monochloramine suppresses the proliferation of colorectal cancer cell line Caco-2 by both apoptosis and G2/M cell cycle arrest. Cell Biochem Funct 2013; 32: 188-193.

15 Spencer WA, Jeyabalan J, Kichambre S, Gupta RC. Oxidatively generated DNA damage following $\mathrm{Cu}(\mathrm{II})$-catalysis of dopamine and related catecholamine neutotransmitters and neurotoxins: role of reactive oxygen species. Free Radic Biol Chem 2011; 50: 139-147.

16 Zafri Humayun M, Ayyappan V. Potential roles for DNA replication and repair functions in cell killing by streptomycin. Mut Res 2013; 749: 87-91.

17 Su MY, Huang HY, Li L, Lu YH. Protective effects of 2'4'-dihydroxy-6'- methoxy-3'5'-dimethylchalcone to PC12 cells against cytotoxicity induced by hydrogen peroxide. J Agric Food Chem 2011; 59: 521-527.

18 Maesaka JK, Palaia T, Frese L, Fishbane S, Ragolia L. Prostaglandin D(2) synthase induces apoptosis in pig kidney LLC-PK1 cells. Kidney Int 2001; 60: $1692-1698$.

19 Hsiao PW, Chang CC, Liu HF, Tsai CM, Chiu TH, Chao JI. Activation of p38 mitogen-activated protein kinase by celecoxib oppositely regulates surviving and gamma-H2AX in human colorectal cancer cells. Toxicol Appl Pharmacol 2007; 222: 97-104.

20 Wu EK, Sung JJ, Lee CW, Yu J, Cho CH. Cyclooxygenase-2 in tumorigenesis of gastrointestinal cancers: an update on the molecular mechanisms. Cancer Lett 2010; 295: 7-16.

21 Fridovich I. Oxygen: how do we stand it? Med Princ Pract 2013; 22: 131 137.

22 Fujimoto Y, Morinaga K, Abe M, Kitamura T, Sakuma S. Selenite induces oxidative DNA damage in primary rat hepatocyte cultures. Toxicol Lett 2009; 191: 341-346.

23 Das U. A radical approach to cancer. Med Sci Monit 2002; 8: RA79-RA92.

24 Dreher D, Junod AF. Role of oxygen free radicals in cancer development. Eur J Cancer 1996; 32A: 30-38.

25 Linder N, Lundin J, Isola J, Lundin M, Raivio KO, Joensuu H. Downregulated xanthine oxidoreductase is a feature of aggressive breast cancer. Clin Cancer Res 2005; 11: 4372-4381.

26 Linder N, Haglund C, Lundin M, et al. Decreased xanthine oxidoreductase is a predictor of poor prognosis in early-stage gastric cancer. $J$ Clin Pathol 2006; 59: 965-971.

27 Linder N, Martelin E, Lundin M, et al. Xanthine oxidoreductase-clinical significance in colorectal cancer and in vitro expression of the protein in human colon cancer cells. Eur J Cancer 2009; 45: 648-655.

28 Houston M, Estevez A, Chumley $\mathrm{P}$, et al. Binding of xanthine oxidase to vascular endothelium. Kinetic characterization and oxidative impairment of nitric oxide-dependent signaling. J Biol Chem 1999; 274: 4985-4994.

29 Hewinson J, Stevens CR, Millar TM. Vascular physiology and pathology of circulating xanthine oxidoreductase: from nucleotide sequence to functional enzyme. Redox Rep 2004; 9: 71-79. 